Khmil S. V., Drozdovska Yu. B. Management of women with infertility and uterine leiomyoma in assisted reproductive technology programs. Journal of Education, Health and Sport. 2020;10(10): 344-357. eISSN 2391-8306. DOI http://dx.doi.org/10.12775/JEHS.2020.10.10.033

https://apcz.umk.pl/czasopisma/index.php/JEHS/article/view/JEHS.2020.10.10.033

https://zenodo.org/record/4535889

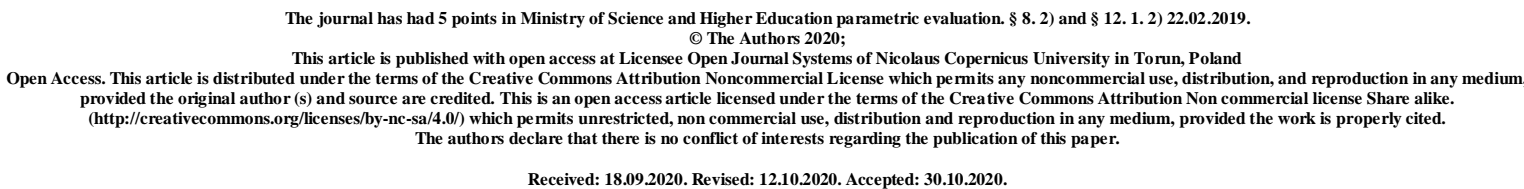

UDC 618. 177-089.888.11-006.363.03/618.14.004.14

\title{
MANAGEMENT OF WOMEN WITH INFERTILITY AND UTERINE LEIOMYOMA IN ASSISTED REPRODUCTIVE TECHNOLOGY PROGRAMS
}

\author{
S. V. Khmil ${ }^{1,2}$, Yu. B. Drozdovska ${ }^{1}$
}

\section{${ }^{1}$ SHEI "I. Horbachevsky Ternopil National Medical University of the MoH of Ukraine", Ternopil, Ukraine \\ ${ }^{2}$ Medical Center "Clinic of Prof. Stefan Khmil", Ternopil, Ukraine}

\begin{abstract}
Khmil, Stefan Volodymyrovych - Professor of the Department of Obstetrics and Gynecology No. 1, SHEI "I. Horbachevsky Ternopil National Medical University of the MoH of Ukraine", honored scientist of Ukraine, professor, doctor of medicine, director of Medical Center "Clinic of Prof. Stefan Khmil".

Drozdovska, Yuliia Bohdanivna - a post-graduate student of the Department of Obstetrics and Gynecology No. 1, SHEI "I. Horbachevsky Ternopil National Medical University of the MoH of Ukraine"; tel.: +38 (068) 583-67-39.
\end{abstract}

\section{Abstract}

In the structure of female infertility, one of the important causes is the uterine factor of infertility, namely, uterine leiomyoma, which is diagnosed in $13.3-24.0 \%$ of cases and leads to loss of reproductive function and pregnancy pathology.

Aim of research: to increase the incidence of pregnancy in infertile women with uterine leiomyoma by analyzing the main factors in the development of this pathology and optimizing the treatment and prevention complex.

Material and research methods. A randomized clinical trial was performed among $175(29.0 \%)$ women of reproductive age with a UL diagnosis, and the control group (CG) of 
32 somatically healthy women with normal menstrual and reproductive functions, who were divided into the following groups: Main Group A (MG) - 137 women with UL, who were further divided into subgroups for evaluation of the treatment: subgroup A1 - 55 women with UL after laparoscopy and hysteroscopy with the proposed treatment complex (TC), subgroup A2 - 45 women with UL after hysteroscopy and TC, subgroup A3 - 37 women with UL and the proposed drug treatment without surgical removal of UL; comparison group B - 38 women with UL and conventional treatment.

Results. The age of the examined patients was $(33.9 \pm 7.8)$ years $(26-42$ years), BMI $\left.(23.5 \pm 5.2) \mathrm{kg} / \mathrm{m}^{2}, \mathrm{AMH}-1.8 \mathrm{ng} / \mathrm{ml}(0.4-5), 2 \mathrm{ng} / \mathrm{ml}\right)$. The duration of infertility was $2-$ 15 years on average $(5.4 \pm 0.5$ years). Primary infertility was diagnosed in 43 patients (24.5\%), and secondary - in 132 women (75.5\%). 93 (53.7\%) women developed hypermenorrhea, of which one in three indicated a history of anemia. 31 (17.7\%) women complained of algodysmenorrhea; in 43 (24.6\%) women, dysmenorrhea occurred after the appearance of uterine fibroids, and 23 women (13.2\%) had irregular menstruation.

During hysteroresectoscopy, single submucosal nodes "on the pedicle", which had clear contours, a rounded shape, a dense consistency, and deformed the uterine cavity, were found in $71(40.8 \%)$ patients. Of these, 51 (71.8\%) nodes were whitish in color with isolated small hemorrhages, and in the remaining $20(28.2 \%)$ cases, the nodes were covered with a lace of stretched and altered blood vessels.

Analysis of the location and size of the nodes revealed that in every third patient $(25$ patients, $35.2 \%$ ) the size of the node was about $2.5 \mathrm{~cm}$, in every fourth (19 patients, 26.7\%) nodes were up to $4 \mathrm{~cm}$, in other patients (27 patients, 38.0\%) the nodes were up to $5 \mathrm{~cm}$ and greater in size

Interstitial-submucosal myomas with a combination of subserous nodes were diagnosed in $104(59.2 \%)$ of the examined women and visualized as a bulge of one of the uterine walls.

During hysteroresectoscopy, we visualized endometrial hyperplasia in $89(50.8 \%)$ patients, which was subsequently confirmed histologically in 67 (38.3\%) women, and secretory transformation of the endometrium in the remaining $22(12.5 \%)$. In $22(12.6 \%)$ patients, we observed hysteroscopic signs of chronic endometritis; this diagnosis was also confirmed morphologically, which was manifested by uneven thickening of the endometrium and micropolyps.

The use of our improved algorithm of rehabilitation measures allowed to reduce the period of menstrual bleeding in $42(48.8 \%)$ women in group A2, which was 1.3 times more 
effective than in the comparison group and 1.4 times more effective than in patients of group A3. Menstrual discharge was 1.9-fold and 1.8-fold lower compared to A1 women who refused surgery and 1.2-fold lower than in the comparison group. The effectiveness of the proposed treatment was analyzed, and the frequency of pregnancy was evaluated; findings indicate that the highest efficiency was observed in women of group A2 - 31.1\% of cases, which was 2 times higher than the comparison group and 2.3 times higher than in group A3.

Conclusion. Uterine leiomyoma is mainly the cause of infertility due to a mechanical factor. Laparo- and hysteroresectoscopy is the optimal method of pre-pregnancy treatment for women with uterine leiomyoma who are undergoing infertility treatment with assisted reproductive technologies. Laparo- and hysteroresectoscopy is an organ-sparing operation that has a number of advantages: easy postoperative period, no adhesions, which, in turn, increases the frequency of pregnancy and reduces premature delivery.

Key words: uterine leiomyoma; laparo- and hysteroscopy; controlled ovarian stimulation; assisted reproductive technologies.

\title{
МЕНЕДЖЕМЕНТ ЛЕЧЕНИЯ ЖЕНЩИН С БЕСПЛОДИЕМ НА ФОНЕ МИОМЫ МАТКИ В ПРОГРАММЕ ВСПОМОГАТЕЛЬНЫХ РЕПРОДУКТИВНЫХ ТЕХНОЛОГИЙ
}

\author{
С. В. Хмиль, Ю. Б. Дроздовська
}

\section{Резюме}

В структуре женского бесплодия одной из важных причин считают маточный фактор бесплодия, а именно, лейомиому матки, которая диагностируется в 13,3-24,0\% и ведет к потере репродуктивной функции и патологии беременности.

Цель исследования: повысить частоту наступления беременности у бесплодных женщин с лейомиомой матки путем анализа основных факторов развития данной патологии и оптимизации лечебно-профилактического комплекса.

Материалы и методы. Рандомизированное проспективное клиническое исследование проведено среди 175 (29,0\%) женщин репродуктивного возраста, у которых диагностирован ЛМ и контрольная группа (КГ) 32 соматически здоровых женщин с нормальной менструальной и репродуктивной функции, которые были разделены на следующие группы: основная (ОГ) А группа - 137 женщин с ЛМ, которая в дальнейшем для оценки проведенного лечения разделена на подгруппы A1 - 55 
женщин с ЛМ после лапаро- и гистероскопии с предложенным лечебным комплексом (ЛК), А2 - 45 женщин с ЛМ после гистероскопии и ЛК, А3 - 37 с ЛМ и предложенным медикаментозным лечением без оперативного удаления ЛМ; сравнения (СГ) группа 38 женщин с ЛМ и общепринятым лечением.

Результаты. Возраст обследованных пациенток составил $(33,9 \pm 7,8)$ года $(26-42$ лет), ИМТ - (23,5 \pm 5,2) кг / м², АМГ - 1,8 ng / ml (0,4-5 $2 \mathrm{ng} / \mathrm{ml})$. Продолжительность бесплодия - 2-15 лет в среднем $(5,4 \pm 0,5)$ года. Первичное бесплодие диагностировано в 43 пациенток (24,5\%), а вторичное - в 132 женщин (75,5\%). В 93 (53,7\%) женщин проявлялась гиперменорея, из них, у каждой третьей диагностирована анемия в анамнезе. На альгодисменорею жаловалось 31 (17,7\%) женщин, причем дисменорея 43 (24,6\%) возникла после появления миомы матки, нерегулярные менструации - у 23 женщин (13,2\%).

В 71 (40,8\%) пациенток во время проведения гистерорезектоскопии обнаружили единичные субмукозные узлы «на ножке», которые имели четкие контуры, круглую форму, плотную консистенцию, деформировали полость матки. Из них в 51 (71,8\%) узлы имели беловатый цвет с редкими мелкими кровоизлияниями, в оставшиеся 20 (28,2\%) были покрыты кружевом растянутых и измененных кровеносных сосудов.

Проведенный анализ локализации и размеров узлов обнаружил что у каждой третьей пациентки 25 (35,2\%) размер узла составил около 2,5 см, в каждой четвертой 19 (26,7\%) был до 4 см, в других больных 27 ( 38,0\%) размеры до 5 см и более.

Интерстициальный-подслизистые с сочетанием субсерозных миоматозные узлы были диагностированы у 104 (59,2\%) обследуемых женщин и визуализировались как выпячивание одной из стенок матки.

Во время проведения гистерорезектоскопии мы визуализировали в 89 (50,8\%) гиперплазию эндометрия, которую в дальнейшем у 67 (38,3\%) женщин было подтверждено гистологически, у остальных 22 (12,5\%) была секреторная трансформация эндометрия. В 22 (12,6\%) кроме гистероскопических картины хронического эндометрита был также подтвержден этот диагноз морфологически, который проявлялся неравномерным утолщением эндометрия, микрополипами и симптомом «манной крупы»).

Использование усовершенствованного нами алгоритма реабилитационных мероприятий позволяет сократить срок менструального кровотечения у 42 (48,8\%) случаев женщин группы А2, что в 1,3 раза эффективнее чем в группе сравнения и в 1,4 раза по сравнению с пациентками группы А3. В 1,9 раза уменьшено объем 
менструальных выделений у женщин А2 и 1,8 раза А1 по сравнению с женщинами группы A3, которые отказались от оперативного лечения и в 1,2 раза в группе сравнения. Проведенный анализ эффективности предложенного лечения и оценены частоту наступления беременности, в результате которого самая высокая эффективность наблюдается у женщин группы А2 - 31,1\% случаев, в 2 раза больше с группой сравнения и в 2,3 раза с группой А3.

Выводы. Лейомиома матки в основном являются причиной бесплодия за счет механического фактора. Лапаро- и гистерорезектоскопия является оптимальным методом прегравидарной подготовки у женщин с лейомиомой матки, которые проходят лечение бесплодия путем использования вспомогательных репродуктивных технологий. Лапаро- и гистерорезектоскопия является органосохраняющей операцией, имеет ряд преимуществ: легкий послеоперационный период, отсутствие спаечного процесса, что, в свою очередь, повышает частоту наступления и уменьшает невынашивания беременности.

Ключевые слова: лейомиома матки; лапаро- и гистероскопия; контролируемая стимуляция яичников; вспомогательные репродуктивные технологии.

The connection of the publication with scheduled research. This paper is part of the research by TNMU departments under the title "Clinical and pathogenetic aspects of diagnosis, treatment and prevention of complications in women with reproductive dysfunction and concomitant somatic extragenital pathology", state registration No. $0116 u 003909$.

\section{Introduction}

The analysis of publications by Ukrainian and foreign researchers shows that infertile marriages make up from 10.0 to $20.0 \%$ [1, 2, 4]. In the structure of female infertility, the uterine factor is one of the leading factors in the development of both secondary and primary infertility. The most common pathology that affects female reproductive function and pregnancy is uterine leiomyoma (UL), which occurs in $13.3-24.0 \%[1,3,5]$. The frequency of UL significantly increases to $35.0-45.0 \%$ in women after 35 years, with internal endometriosis increasing to $8-10 \%$ and endometrial hyperplasia to $10 \%$. The main triggers of UL growth are the imbalance in the hypothalamic-pituitary-ovarian system due to changes in the levels of FSH, LH, prolactin, progesterone, and estrogen; and the reduction in the uterus response to the influence of steroid hormones due to changes in the formation of local autonomous mechanisms of growth support [2, 6, 8]. Clinical studies demonstrating that 
reproductive function is restored in 30.0 - 37.0\% of patients after myomectomy indicate that UL plays a leading role in the genesis of infertility due to the location of nodes near the tubal angles of the uterus and deformation of its cavity $[2,7,9,10]$. To date, the issue of the optimal method of treatment for women with uterine leiomyoma and unrealized reproductive potential has not been reliably resolved. Thus, the study of modern methods of surgical treatment of patients with this tumor process constitutes an urgent task of obstetrics, gynecology and reproductive medicine.

Aim of research: to increase the incidence of pregnancy in infertile women with uterine leiomyoma by analyzing the main factors in the development of this pathology and optimizing the treatment and prevention complex.

\section{Materials and research methods}

A randomized clinical trial was performed during 2014 - 2020 at the Medical Center "Clinic of Prof. Stefan Khmil". During stage I, the analysis of outpatient histories of 603 women of reproductive age with operations on pelvic organs was carried out; further, 175 (29.0\%) women of reproductive age with a UL diagnosis, and the control group (CG) of 32 somatically healthy women with normal menstrual and reproductive functions were included in the prospective analysis. The above women were divided into the following groups: Main Group A (MG) - 137 women with UL, who were further divided into subgroups for evaluation of the treatment: subgroup A1 - 55 women with UL after laparoscopy and hysteroscopy with the proposed treatment complex (TC), subgroup A2 - 45 women with UL after hysteroscopy and TC, subgroup A3 - 37 women with UL and the proposed drug treatment without surgical removal of UL; comparison group B - 38 women with UL and conventional treatment.

All patients underwent detailed traditional clinical and laboratory gynecological examinations in accordance with the local protocols approved in the clinic for the management of patients with uterine infertility and Order of the Ministry of Health of Ukraine of 09.09.2013 No. 787 "On approval of the procedure for Assisted Reproductive Technologies in Ukraine".

A thorough clinical and laboratory examination was conducted, and the gynecological history of patients was studied, including previous surgeries on the pelvic organs and the infertility interval. All data were entered in the personal electronic card of each patient.

The size of the fibroids did not exceed $3-5 \mathrm{~cm}$ in diameter; all women had a deformed uterine cavity and a history of unsuccessful attempts at in vitro fertilization. All patients in the main group were offered hysteroresectoscopy as treatment and preparation for assisted 
reproductive technology programs, but patients in subgroup A3 refused surgery. Women with submucosal-intramural myomas were hormonally prepared with gonadotropin-releasing hormone agonists (intramuscular Diferelin $3.75 \mathrm{mg}$ once every 28 days for 3 months) before myomectomy. The purpose of preoperative treatment is to reduce the size of the node (30$40 \%$ ), with the node being "pushed" into the uterine cavity.

Samsung (Medison) SonoAce X8 and Voluson E8 Expert from GE (USA) were used for ultrasound examination of the pelvic organs. Hysterosalpingography (HSG) X-ray was performed with a digital angiographic device Multistar (Siemens, Germany) with photographs of the movement of contrast in the uterine cavity and fallopian tubes. The examination was performed in the first phase of the menstrual cycle (7-11 days) using contrast agents Echovist300.

Magnetic resonance imaging was done on a magnetic resonance tomograph Siemens 1.5 T MAGNETOM Avanto (Germany) using T1 and T2 weighted images, pulse sequences Turbo SpinEcho, HASTE (Half Fourier Acquisition Single Shot), and FLASH (Fast Low Angle Single Shot). The surgical treatment, i.e., laparoscopy and hysteroscopy, was performed in the main and comparison groups using the equipment manufactured by Karl Storz (Germany) according to the conventional method (Khmil, S.V., 2014), with subsequent pathohistological and immunohistochemical testing of the obtained material.

In this study, standard clinical and laboratory examinations were used according to the regulations (local orders) for outpatient and inpatient obstetric and gynecological care before and after myomectomy. The consequences of surgical treatment of UL and the postoperative functions, namely, menstrual, sexual, and reproductive functions, were evaluated.

Common rehabilitation measures: traditional antibacterial therapy, nonsteroid analgesics; 2 months before surgery and one month after surgery - one of the GnRH agonists according to the order of the Ministry of Health of Ukraine No. 582 of 15.12.2003 on approval of the clinical protocol "Leiomyoma of the uterus".

Statistical research methods were applied using the licensed software program Statistica (version 10; Statsoft, USA). Traditional methods of parametric statistics (average value, error of average value) were used to process quantitative values. Significance of differences between group means was calculated based on Student's criterion for the level of statistical significance: $\mathrm{p}<0.05(\mathrm{x}=95 \%)$.

\section{Findings and discussion}

The age of the examined patients was $(33.9 \pm 7.8)$ years $(26-42$ years $)$, BMI - $(23.5 \pm$ $\left.5.2) \mathrm{kg} / \mathrm{m}^{2}, \mathrm{AMH}-1.8 \mathrm{ng} / \mathrm{ml}(0.4-5), 2 \mathrm{ng} / \mathrm{ml}\right)$. The duration of infertility was $2-15$ 
years on average $(5.4 \pm 0.5)$ years. Primary infertility was diagnosed in 43 patients $(24.5 \%)$, and secondary - in 132 women (75.5\%) (Fig. 1). The mean age of onset of menarche was $(13.0 \pm 0.5)$ years and was characterized by a regular menstrual cycle. Married couples with male infertility factor were not included in this study.

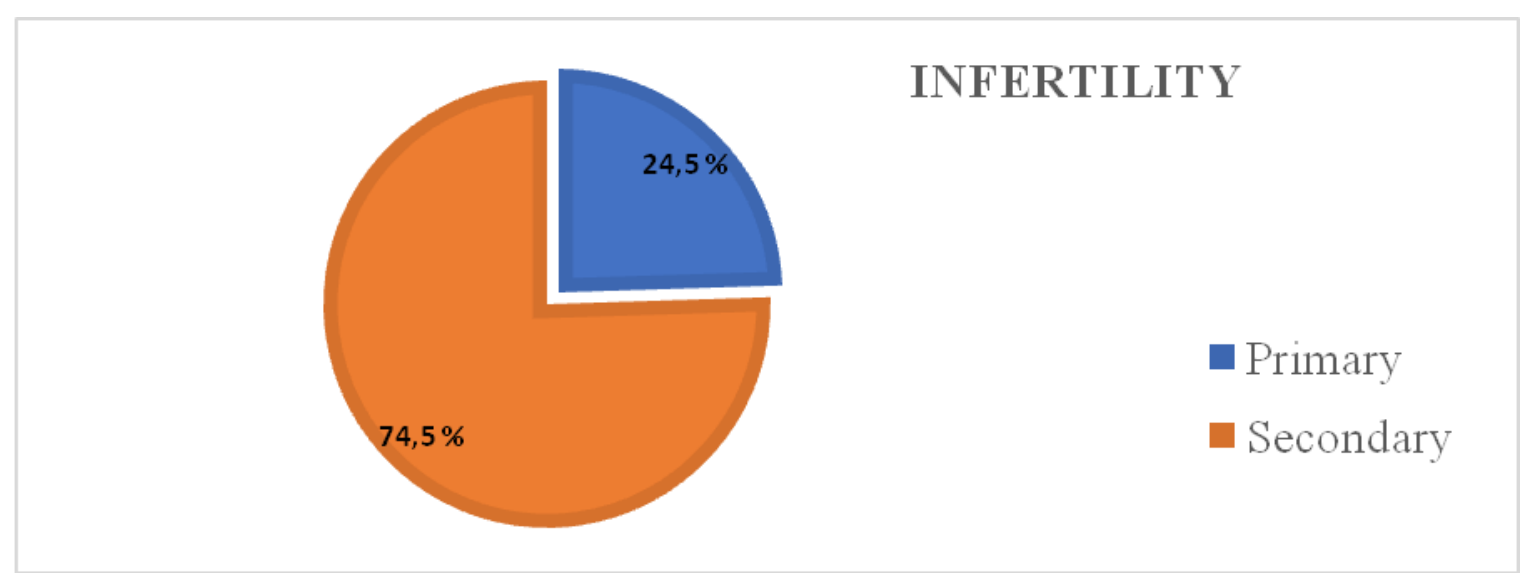

Fig. 1. The structure of infertility in the examined patients

After analyzing the social status of the examined women, we found that in the main group employees made up $37.2 \pm 3.9 \%$, housewives $-40.5 \pm 3.6 \%$, workers $-11.8 \pm 2.6 \%$, students $-10.5 \pm 2.5 \%$. In the control group, employees accounted for $52.0 \pm 7.1 \%$, housewives $-28.4 \pm 6.4 \%$, workers $-10.2 \pm 4.5 \%$, students $-9.4 \pm 4.1 \%$.

We studied the frequency of extragenital pathology (Fig. 1), where the most common pathology was that of the endocrine system, the structure of which was dominated by thyroid disease, which, in fact, is a reasonable figure, because the examined women live in an endemic iodine deficiency area. The incidence of anemia was high at $19.7 \%$ in the main and $18.4 \%$ in the comparison group, with half of the patients indicating a history of two or three courses of anti-anemic therapy. Respiratory diseases made up $17.5 \%$ and $18.4 \%$ (chronic rhinitis $-9.1 \%$, chronic tonsillitis $-5.8 \%$ ) d diseases of the gastrointestinal tract affected $16.0 \%$ and diseases of genitourinary system $-10.3 \%$ of the examined women. One in ten patients was diagnosed with overweight. Thus, extra-genital pathology was found in half of the patients, while every third of them had a combination of 2 or 3 nosologies.

On average, the menstrual cycle lasted $28.5 \pm 2.1$ days (from 22 to 40 days) and in 152 (86.8\%) women it was regular. 93 (53.7\%) women developed hypermenorrhea, of whom one in three indicated a history of anemia, which is characteristic of the submucosal localization of fibroids according to S. Abramson et al. (2014). 31 (17.7\%) women complained of algodysmenorrhea, and in $43(24.6 \%)$ dysmenorrhea started after the appearance of uterine 
fibroids. Irregular menstruation was indicated by 23 women (13.2\%), Fig. 2.

Table 1

The structure of extragenital pathology

\begin{tabular}{|l|c|c|c|}
\hline \multirow{2}{*}{\multicolumn{1}{|c|}{ Disease }} & \multicolumn{3}{|c|}{ Groups } \\
\cline { 2 - 4 } & $\begin{array}{c}\text { Main } \\
(\mathrm{n}=137), \text { abs., } \%\end{array}$ & $\begin{array}{c}\text { Comparison } \\
(\mathrm{n}=38), \text { abs., } \%\end{array}$ & $\begin{array}{c}\text { Control } \\
\mathrm{n}=32, \text { abs., } \%\end{array}$ \\
\hline Gastrointestinal tract: & $22(16.1)$ & $6(15.8)$ & $5(15.6)$ \\
- chronic gastritis & $6(4.4)$ & $2(5.3)$ & $2(6.25)$ \\
- cholecystitis & $4(2.9)$ & $1(2.6)$ & $1(3.1)$ \\
- colitis & $4(2.9)$ & - & - \\
- pancreatitis & $3(2.2)$ & $1(2.6)$ & - \\
- ulcer of the duodenum & $3(2.2)$ & $2(5.3)$ & $2(6.25)$ \\
\hline Cardiovascular diseases: & $10(7.3)$ & $3(7.9)$ & $2(6.25)$ \\
\multicolumn{1}{|c}{ - arterial hypertension } & & & $6(18.7)$ \\
\hline Respiratory system: & $24(17.5)$ & $7(18.4)$ & $2(6.25)$ \\
- chronic rhinitis & $12(8.8)$ & $4(10.5)$ & $3(9.4)$ \\
- chronic tonsillitis & $8(5.8)$ & $2(5.3)$ & $1(3.1)$ \\
- chronic bronchitis & $4(2.9)$ & $1(2.6)$ & $4(12.5)$ \\
\hline Genitourinary system: & $13(9.4)$ & $5(13.2)$ & $2(6.25)$ \\
- cystitis & $5(3.6)$ & $2(5.3)$ & $2(6.25)$ \\
- chronic pyelonephritis & $7(5.1)$ & $3(7.9)$ & $10(31.25)$ \\
\hline Endocrine: & $43(31.4)$ & $12(31.6)$ & $6(18.7)$ \\
- diffuse non-toxic goiter & $27(19.7)$ & $8(21.1)$ & $4(12.5)$ \\
- obesity, stage 1-2 & $16(11.8)$ & $4(10.5)$ & $2(6.25)$ \\
\hline Anemia & $27(19.7)$ & $7(18.4)$ & \\
\hline
\end{tabular}

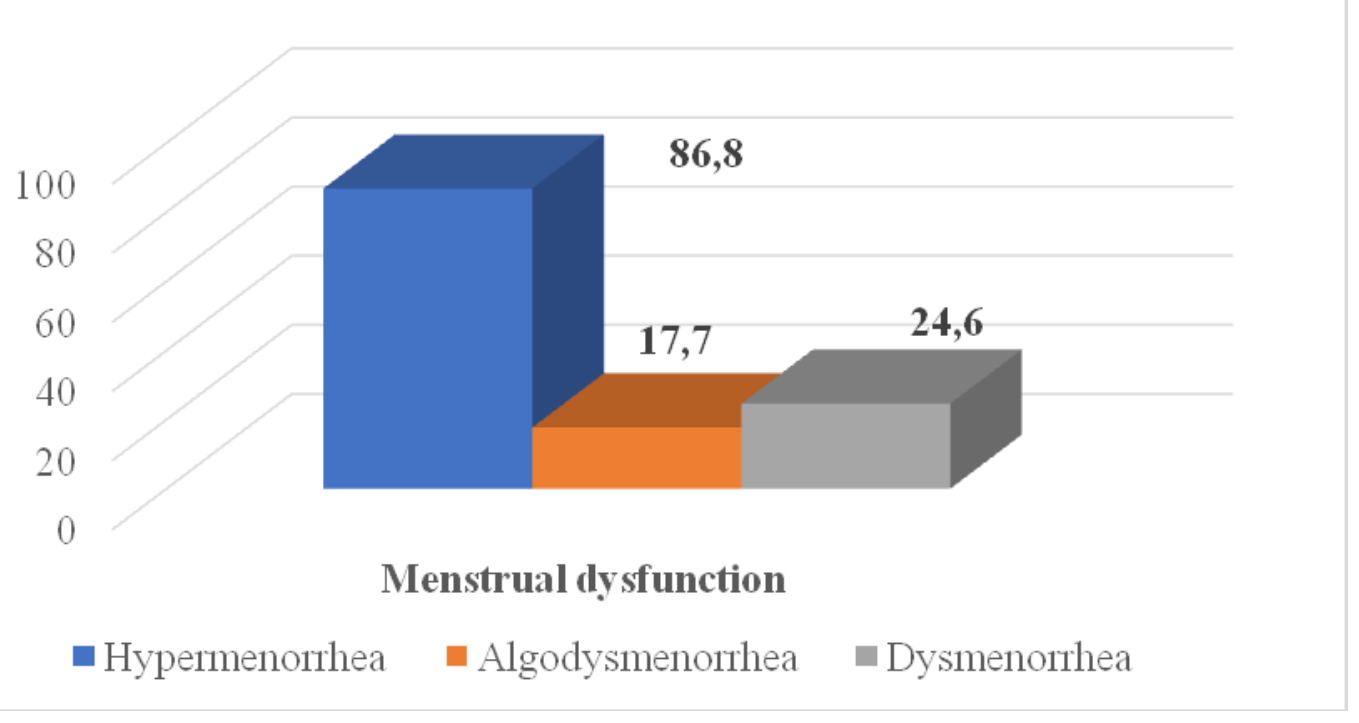

Fig. 2. Menstrual dysfunction

Analysis of the concomitant gynecological pathology revealed a high incidence of 
inflammatory disease of the uterine appendages - $132(75.4 \%)$, endometrial hyperplastic processes - 111 (63.4\%), ovarian cysts - 37 (21.1\%) and endometrioid disease - $13(7.4 \%)$, which indicates the general links between the pathogenetic process of uterine leiomyoma and other benign processes of the reproductive system (Tatarchuk T.F. et al., 2012; Nkemayim D.C. et al., 2015; Kornatska A.G. et al., 2017).

Based on our findings, we can assume that the development of uterine leiomyoma in every third patient is a major factor in infertility, but it should be noted that most patients were diagnosed with a combination of UL and a concomitant gynecological pathology, i.e., pelvic inflammatory disease, endometrial pathology, and endocrine disorders. Hereditary predisposition also plays an important role, as well as traumatization of the endometrium and myometrium during diagnostic scraping of the uterine cavity for endometrial pathology, impaired uterine pregnancy, and medical abortion.

One of the diagnostic methods of uterine pathology is ultrasound diagnosis with color Doppler mapping (CDM), which allows to assess the location, volume, number of nodes, and the blood supply; it is characterized by increased uterine size (thickness), deformation of contours and the appearance of isoechoic myometrium with fairly clear contours (Seinera P. et al., 2014; Hallez J.P., 2015). In 119 patients (68.0\%), we found a hyperechogenic formation with induration on the periphery (capsule), which corresponds to the processes in the altered myomatous tissue due to sclerosis and fibrosis. The CDM found single loci of blood flow in the center and moderate blood flow to the periphery, while the index of resistance (IR) was $0.61 \pm 0.05$ in the node and $0.69 \pm 0.07$ in the myometrium. $56(32.0 \%)$ of patients were diagnosed with single or multiple hyperechogenic formations with an inhomogeneous structure. CDM showed a large number of small vessels (intensive neovascularization), low vascular resistance, expressed brightness of a color signal that signified high speed and inhomogeneity of blood flow in the UL. The resistance index in myomatous nodes was, on average, $0.36 \pm 0.59$, in the myometrium $-0.55 \pm 0.12$. In our study, we found a combination of submucosal-intramural nodes with subserous nodes in $104(59.4 \%)$ patients and submucosal nodes in $71(40.8 \%)$ patients.

It has been proved that hysteroscopy allows to diagnose submucosal localization of a node, its size and width. We used the general hysteroscopic classification of submucosal nodes by ESGE (European Society of Endoscopic Gynecology). Hysteroresectoscopy was performed mechanically and electrosurgically on day 6-10 of the menstrual cycle under general anesthesia. Patients were placed in a dorsal lithotomy position. After pre-treatment of the operating field with antiseptic solutions, under aseptic conditions, the cervix was exposed 
in mirrors; using ball forceps, the cervix was paracervically fixed using the anterior lip. The uterine probe was used to measure the direction of the axis and the length of the uterus. The cervical canal was dilated using Hegar dilators up to No. 8. After that, a hysteroscope was inserted into the uterine cavity. Under the control of a television camera, we gradually examined and assessed the condition of the uterine cavity, the uterine angles, the tubal cells, the condition of the endometrium, the presence and location of pathological formations, and the cervical canal. Surgery began only after a complete assessment of the uterine cavity. Submucosal myomas on a thin pedicle in the uterine fundus were removed mechanically, with the help of a cutting loop. Electrosurgical (loop electrode) resection was used for myomatous nodes with submucosal-intramural location and submucosal nodes on a thick pedicle. In this technique, the tissue of the node is gradually cut in thin strips (chipped). The movement of the hysteroscope should be strictly towards the surgeon (to prevent perforation of the uterus). During the operation, the tissues of the myoma are periodically removed. All patients received adequate hemostatic, antibacterial and hormonal therapy after surgery.

During hysteroresectoscopy, single submucosal nodes "on the pedicle" which had clear contours, a rounded shape, a dense consistency, and deformed the uterine cavity were found in $71(40.8 \%)$ patients. Of these, $51(71.8 \%)$ nodes were whitish in color with isolated small hemorrhages, and in the remaining 20 (28.2\%) cases the nodes were covered with a lace of stretched and altered blood vessels.

Analysis of the location and size of the nodes revealed that in every third patient (25 patients, $35.2 \%$ ), the size of the node was about $2.5 \mathrm{~cm}$, in every fourth patient (19 patients, $26.7 \%$ ), nodes were up to $4 \mathrm{~cm}$, in other patients ( 27 patients, $38.0 \%$ ) the nodes were up to 5 $\mathrm{cm}$ and greater in size.

Interstitial-submucosal myomas with a combination of subserous nodes were diagnosed in $104(59.2 \%)$ of the examined women and visualized as a bulge of one of the uterine walls.

During hysteroresectoscopy, we visualized endometrial hyperplasia in $89(50.8 \%)$ patients, which was subsequently confirmed histologically in 67 (38.3\%) women, and secretory transformation of the endometrium was found in the remaining 22 women $(12.5 \%)$. In $22(12.6 \%)$ patients, we observed hysteroscopic signs of chronic endometritis; this diagnosis was also confirmed morphologically, which was manifested by uneven thickening of the endometrium and micropolyps.

Regarding further treatment measures, for 2-3 months before the start of controlled ovulation stimulation, the examined women received pre-pregnancy treatment with vitamin 
complex "FT-500 Plus" containing: inositol - $2000 \mathrm{mg}$, vitamin C - $160 \mathrm{mg}$, vitamin E - 12 $\mathrm{mg}$, folic acid $-400 \mathrm{mcg}$, selenium $-55 \mathrm{mcg}$, glutathione $-50 \mathrm{mg}$, zinc $-10 \mathrm{mg}$, lutein -3 mg. Controlled stimulation of superovulation was performed based on short protocols using recombinant gonadotropin corypholitropin-alpha - "ELONVA". This drug has a prolonged effect (7-8 days). On the $5^{\text {th }}-7^{\text {th }}$ day of stimulation, when the follicles reached the size of 14 - $15 \mathrm{~mm}$ in diameter subject to folliculometry control, a gonadotropin-releasing hormone antagonist "Orgalutran" $0.25 \mathrm{mg}$ was prescribed daily. On day 8 , superovulation stimulation was continued with recombinant Puregon FSH until final oocyte maturation (presence of at least 3 oocytes larger than $17 \mathrm{~mm}$ in diameter), using the gonadotropin-releasing hormone agonist Diferelin or human chorionic hormone as a trigger dosed at 5,000 or 10,000 IU. In 36 - $37 \mathrm{~h}$ after ovulation trigger administration, follicle puncture was performed followed by oocyte aspiration. After a preliminary assessment of the condition of the eggs by embryologists, they were fertilized by ICSI. Only oocytes in prophase I of the second meiotic division are suitable for fertilization. Fertilization of eggs and cultivation of embryos with their subsequent transfer into the uterine cavity or vitrification on days 5 - 6 (blastocyst stage) was carried out in an embryological laboratory. Embryo transfer to the uterine cavity was performed in both fresh and cryo-cycles, depending on the risk of ovarian hyperstimulation syndrome in patients. Patients received maintenance therapy with estrogen ("Proginova") and progestogen drugs until pregnancy result. Pregnancy was confirmed 2 weeks after embryo transfer by blood test for $\beta$-HCG. With a positive result, maintenance therapy was continued until 8-12 weeks of pregnancy.

After the proposed treatment, we obtained a reduction in menstrual bleeding in group A2 in $42(48.8 \%)$ cases, which is 1.3 times more effective than in the comparison group and 1.4 times more than in patients of group A3. Menstrual discharge was 1.9-fold and 1.8-fold lower compared to A1 women who refused surgery and 1.2-fold lower than in the comparison group. The effectiveness of the proposed treatment was analyzed, and the frequency of pregnancy was evaluated; findings indicate that the highest efficiency is observed in women of group A2 $-31.1 \%$ of cases, which is 2 times higher than in the comparison group and 2.3 times higher than in group A3 (Table 2).

The data of the clinical study show that a comprehensive treatment approach, namely surgical treatment of submucosal leiomyomas with the proposed drug therapy allows to achieve the desired pregnancy in every third patient with uterine infertility and normalization of the functional state of reproductive organs. 
Restoration of reproductive function in the examined women

\begin{tabular}{|c|c|c|c|c|c|}
\hline \multirow[b]{2}{*}{ Indicator } & \multicolumn{5}{|c|}{ Groups } \\
\hline & $\begin{array}{c}\text { A1, } \\
(n=55) \\
\text { abs., \% }\end{array}$ & $\begin{array}{c}\mathrm{A} 2, \\
(\mathrm{n}=45) \\
\text { abs., \% }\end{array}$ & $\begin{array}{c}\text { A3, } \\
(\mathrm{n}=37) \\
\text { abs., \% }\end{array}$ & $\begin{array}{l}\text { Comparison } \\
\text { group } \\
(\mathrm{n}=38) \\
\text { abs., \% }\end{array}$ & $\mathrm{P}_{\mathrm{I}-\mathrm{II}}$ \\
\hline $\begin{array}{l}\text { Reduction of menstrual } \\
\text { bleeding time }\end{array}$ & $\begin{array}{c}24 \\
(43.6)\end{array}$ & $\begin{array}{c}22 \\
(48.8)\end{array}$ & $\begin{array}{c}13 \\
(35.1)\end{array}$ & $\begin{array}{c}14 \\
(36.8)\end{array}$ & $<0.02$ \\
\hline $\begin{array}{l}\text { Decreased menstrual } \\
\text { discharge }\end{array}$ & $\begin{array}{c}16 \\
(29.1)\end{array}$ & $14(31.1)$ & $\begin{array}{c}6 \\
(16.2)\end{array}$ & $\begin{array}{c}10 \\
(26.3)\end{array}$ & $<0.001$ \\
\hline $\begin{array}{l}\text { Pregnancy within a year } \\
\text { - uterine } \\
\text { • ectopic }\end{array}$ & $\begin{array}{c}17(30.9) \\
14(25.4) \\
3(5.5)\end{array}$ & $\begin{array}{c}16(35.6) \\
14(31.1) \\
2(4.4)\end{array}$ & $\begin{array}{l}9(24.3) \\
5(13.5) \\
4(10.8)\end{array}$ & $\begin{array}{l}8(21.0) \\
6(15.7) \\
2(5.3)\end{array}$ & $\begin{array}{l}<0.001 \\
<0.001 \\
>0.05\end{array}$ \\
\hline Spontaneous abortions & $1(1.8)$ & $1(2.2)$ & $1(2.7)$ & $1(2.6)$ & $>0.05$ \\
\hline
\end{tabular}

\section{Conclusion:}

Uterine leiomyoma is mainly the cause of infertility due to a mechanical factor: deformation of the uterine cavity, impaired transport and migration of sperm and egg, impaired embryo implantation and contractile function of the myometrium.

The use of our improved algorithm of rehabilitation measures allowed to reduce the period of menstrual bleeding in $42(48.8 \%)$ women in group A2, which was 1.3 times more effective than in the comparison group and 1.4 times more than in patients of group A3. Menstrual discharge was 1.9-fold and 1.8-fold lower compared to A1 women who refused surgery and 1.2-fold lower than in the comparison group. The effectiveness of the proposed treatment was analyzed, and the frequency of pregnancy was evaluated; findings indicate that the highest efficiency was observed in women of group A2 - 31.1\% of cases, which is 2 times higher than the comparison group and 2.3 times higher than in group A3.

Prospects for further research. Researchers plan to conduct pre-pregnancy therapy and controlled ovarian stimulation based on the short protocol in women with infertility and uterine leiomyoma after the surgical treatment of UL.

\section{References}

1. Doroha O., Iarotska I., Vitiuk A., Strelko H. Optimization of methods of diagnostics and treatment of submucosal leiomyomas in women of reproductive age. Georgian medical news. 2019;12(297): 35-41

2. Zhylka N. Ya. Innovatsiyni pidkhody do likuvannya leyomiomy matky. 
Zdorovye zhenshchiny. 2016; 7 (113): 104-106. (in Ukrainian)

3. N. V. Avramenko, D. Ye. Barkovskyy, O. V. Kabachenko, D. V. Letsyn. Suchasni pohlyady reproduktoloha na etiopatohenez i likuvannya leyomiomy matky. Zaporizkyy medychnyy zhurnal. 2017; № 3 (102): 381-386 (in Ukrainian).

4. A. H. Kornatska, O. O. Revenko, I. S. Kolesnichenko [ta in.] Novi pohlyady na likuvannya leyomiomy matky $\mathrm{v}$ zhinok reproduktyvnoho viku. Reproduktyvna endokrynolohiya. 2017; №4 (36): 82-85 (in Ukrainian)

5. Semenyak A. V., M. Yuzko, I. R. Nitsovych. Leyomioma matky ta vahitnist. Neonatolohiya, khirurhiya ta perynatalna medytsyna. 2018; № 2 (28): 93-98 (in Ukrainian)

6. Jei-Won Moon, Chung-Hoon Kim, Jun-Bum Kim [et al.] Alterations in uterine hemodynamics caused by uterine broids and their impact on in vitro fertilization outcomes. Clin. Exp. Reprod. Med. 2015; Vol. 42 (4): 163-168.

7. L. Deligdish, M. Loewenthal. Endometrial changes associated with myomata of uterus. J. CHn Pathol. 2014; No. 23: 676-680.

8. L.I. Zepiridis, G.F. Grimbizis, B.C. Tarlatzis [et al.] Infertility and uterine broids. Best Pract. Res. Clin. Obstet. Gynaecol. 2016; Vol. 34: 66-73.

9. K. Fischer, N. J. McDannold, C. M. Tempany. Potential of minimally invasive procedures in the treatment of uterine broids: a focus on magnetic resonance-guided focused ultrasound therapy. Int. J. Women's Health. 2015; Vol. 7: 901-912.

10. T. Samejima, K. Koga, H. Naake [et al.] Identifying patients who can improve fertility with myomectomy. Eur. J. Obstet. Gynecol. Reprod. Biol. 2015; Vol. 185: 28-32. 